\title{
SENTENCE ARTICULATION IN BRAZILIAN SIGN LANGUAGE - LIBRAS
}

Articulação de Orações na Língua Brasileira de Sinais - Libras

Articulación de Oraciones en la Lengua Brasileña de Señas - Libras

\section{Bruno Gonçalves Carneiro *1, Carlos Roberto Ludwig ${ }^{2}$}

${ }^{1}$ Doutorando pelo Programa de Pós-Graduação em Letras e Linguística da UFG e professor do Curso de Letras: Libras da UFT, Porto Nacional, Brasil.

${ }^{2}$ Professor do Programa de Pós-Graduação em Letras e do Curso de Letras da UFT, Porto Nacional, Brasil.

*Correspondência: Coordenação do Curso de Letras: Libras, Universidade Federal do Tocantins, Campus de Porto Nacional, Rua 03, Quadra 17, Lote 11, s/n' , Porto Nacional, Tocantins, Brasil. CEP:77.000-00. e-mail brunocarneiro@uft.edu.br

Artigo recebido em 11/08/2018 aprovado em 17/11/2019 publicado em 23/03/2020.

\section{RESUMO}

A articulação de orações é uma estratégia gramatical encontrada em todas as línguas naturais. Esse fenômeno origina construções complexas que se manifestam em um contínuo gradiente (parataxe - hipotaxe - encaixamento), a partir da integração de níveis sintático, semântico e pragmático da língua em uso. O presente estudo é regido por uma perspectiva funcionalista da linguagem e pretende identificar as estratégias de articulação de orações na língua brasileira de sinais, considerando as relações de parataxe, hipotaxe ou encaixamento. Analisamos vídeos provenientes de conversas via redes sociais, produzidos em interação bidirecional e assíncrona de três surdos sinalizantes. Os vídeos foram analisados no Elan, programa multimodal de descrição simultânea de áudio e/ou vídeo. Este estudo está em andamento e aqui apresentamos alguns achados iniciais. Dentre os resultados, destacamos que a libras utiliza diferentes estratégias para articular orações: o uso de justaposição e expressões faciais específicas, bem como o uso de itens lexicais para caracterizar diferentes relações complexas. Assim, as orações complexas da libras incorporam diferentes estratégias para estruturar parataxe, hipotaxe e encaixamento.

Palavras-chave: Orações complexas. Parataxe. Hipotaxe. Subordinação. Libras.

\begin{abstract}
Articulation of sentences is a grammatical strategy found in any natural language. This phenomenon generates complex constructions which appear in a gradient continuum (parataxis - hypotaxis - embedded), based on the integration of syntactical, semantical, and pragmatical levels of the language in use. The current research is based on the functionalist perspective of language and we aim at identifying strategies of articulating sentences in Brazilian Sign Language, taking into account parataxis, hypotaxis and embedded. We analyze videos taken from conversations via social networks, produced in bidirectional and asynchronic interaction by three signing deaf. The videos were analyzed on Elan, a multimodal program which enables simultaneous description of audio and/or video. This is an on-going research and here we discuss some initial findings. Among the results, we enhance that Libras employs different discourse strategies of articulating complex sentences: the use of justaposition and specific facial expressions to articulate complex sentences, as well as the use of lexical items to characterize different complex relations. Thus, complex sentences in Brazilian sign language embodies different strategies to structure parataxis, hypotaxis and embedding.
\end{abstract}

Keywords: Complex sentences. Parataxis. Hypotaxis. Subordination. Brazilian Sign Language. 


\section{RESUMEN}

La articulación de oraciones es una estrategia gramatical encontrada en todas las lenguas naturales. Este fenómeno origina construcciones complejas que se manifiestan en un continuo gradiente (parataxis - hipotaxis encajamiento), a partir de la integración de niveles sintáctico, semántico y pragmático de la lengua en uso. El presente estudio se rige por una perspectiva funcionalista del lenguaje y pretende identificar las estrategias de articulación de oraciones en la lengua de señas brasileña, considerando las relaciones parataxis, hipotaxis o encajamiento. Analizamos videos provenientes de conversaciones vía redes sociales, producidos en interacción bidireccional y asíncrona de tres sordos señantes. Los vídeos fueron analizados en Elan, programa multimodal de descripción simultánea de audio y/o video. Este estudio está en marcha y aquí presentamos algunos resultados iniciales. Entre ellos, destacamos que la libras utiliza diferentes estrategias para articular oraciones complejas: el uso de la yuxtaposición y expresiones faciales especificas para articular oraciones complejas, así como el uso de elementos lexicales para caracterizar diferentes relaciones complejas. Así, las oraciones complejas de libras incorporan diferentes estrategias para estructurar parataxis, hipotaxis y encajamiento.

Descriptores: Oraciones complejas. Parataxis. Hipotaxis. Subordinación. Libras.

\section{INTRODUCTION}

All human languages possess some strategies to combine and form both simple and complex sentences (CARVALHO, 2004). The relations between sentences can be broad, considering the integration of syntactical, semantical and pragmatical components. Consequently, there are different possibilities of intertwining the sentence elements, both primary or secondary. Functionally, connectors can make explicit the relations between sentences, yet they do not determine them. The important aspect for discourse is the type of proposition which emerges from it; thus, the need of a systemic view (NEVES, 2001).

Verbal phrase begins from a verbal predicator. This is the basis of the sentence organization. The predicator sets the argument structure, and from there, other elements are triggered, like the satellites.

Terms that function as arguments need comply certain criteria required by the predicator's semantics. Satellites, however, are not elements required by the predicate. They help to construct the utterance, in other words, they compose the discursive scene and lead the interlocutor to the said message, based on the proposition that is established.
In a simple verbal phrase, the arguments of the verbal predicate are names. In the case of a complex verbal phrase, the argument and / or satellite of a verbal predicate are also verbal phrases, in other words, they are verbs that also require a verbal phrase structure.

This paper aims at identifying the strategies of articulation of sentences in Brazilian Sign Language (henceforward Libras). We analyze videos from conversations via social networks, signed in bidirectional and asynchronic interaction, by three deaf, using Brazilian sign language. The videos were analyzed on Elan, a multimodal program which enables simultaneous description of audio and/or video. This is an on-going study and here we point out some initial findings.

The sentence segmentation happened from the phenomenon of predication, when se identifying the terms (conceptually) verbs. We analyze the constructions whose predicates denote actions. Signs conveying ideas of state, such as BEAUTIFUL in Libras (being beautiful), also considered as verbs (JOHNSTON; SCHEMBRI, 1999), were not taken into account. We also excluded semi-lexicalized structures (classifiers) (ZESHAN, 2003). 
COMPLEX CONSTRUCTIONS:

\section{ARTICULATION OF SENTENCES}

According to Halliday (1985), different types of combination between sentences happen based on the crossing of two axis: tactical and logicalsemantical. The first one is an axis of interdependence, wherein relations of parataxis and hypotaxis are provided, which in turn can appear in various levels. Parataxis establish a notion of correlation between elements of equal status. On the other hand, hypotaxis conveys a notion of dominance and modification, in other words, a relation between a dependent element and its dominant. This relation is applied to all complexes, such as words, groups, phrases or sentences (BRAGA, 2001). Parting from this axis, Carvalho (2004) explains that in both the paratactic and hypotactic structures there occur primary sentences (the primary sentence of a paratactic construction and the dominant of a hypotactic one), as well as secondary sentences (those ones that occur after the primary sentence in a paratactic construction and the dependent ones in a hypotactic construction). It is worth enhancing that the term 'primary' does not convey the meaning of 'main', but the meaning of nuclear or matrix. It is based on it that the other segment of the sentence structure follows. Furthermore, Neves (2001) points out that the primary sentences do not always convey the most important information of discourse.

The second axis, the logical-semantical one, is the functional axis in which the relations of expansion (one sentence expands the other) and projection (one sentence is projected upon the other) emerge. The expansion occurs through the processes of elaboration, extension and enrichment (or enhancement).

Hopper and Traugott (1993 in NEVES, 2001) present a continuum of articulations between sentences, which can be seen between the nucleus and one or more additional nuclei, or between a nucleus and one or more margins. The authors also consider the parameters of dependence (dependence/ interdependence/ independence) and integration (subordination/ co-subordination/ coordination). These parameters evoke a gradience between the relations of parataxis, hypotaxis and subordination (embedded), as depicted in Figure 1.

\section{PARATAXIS -----------HYPOTAXIS
(-) Dependence
$(-)$ Embedded
(+) Dependence
$(-)$ Embedded
(+) Dependence
(+) Embedded \\ -EMBEDDED}

Figure 1. Continuum of dependence and integration between sentences

Source: Neves (2001, p. 63), translated by one of the authors of this paper.

Lehmann (1998) also presents some criteria for the analysis of sentence articulation in natural languages. Both the hierarchical demotion and the syntactic level of subordinate sentence depict the degree of autonomy or integration of the (so-called) subordinate sentence to the primary sentence. A sentence, when affected by the demotion (or declassified), can configure an embedded sentence (a constituent of the primary sentence). Figure 2 demonstrates this continuum of demotion. 
Carvalho (2004) highlights that, from these proposals, the dichotomies between coordination/ subordination, as well as parataxis/ hypotaxis cannot account for all the possibilities of codification of constructions. In this continuum, the possibilities vary in a tenuous way, ranging from a subtler combination to a rather cohesive combination. Parataxis sentences, for example, may involve the phenomenon of juxtaposition (adjacent sentences under the same intonational outline, without using a connector) and coordination (explicit use of a connector). Articulated sentences on the hypotaxis level can comprise both adverbial sentences and explicative adjective sentences, that is to say, those ones that do no function as the argument of the primary (nuclear) sentence but partake in the discursive organization of the speaker (separate information). Finally, the subordinate (or embedded) sentences, which work as complement to a (noun) phrase or modify a noun (restrictive adjective ones), play the role of argument regarding the matrix sentence. However, this does not hamper, for example, that the same kind of complex sentence may have differences in the distributional pattern (CARVALHO, 2004). Juxtaposed sentences, for example, may be articulated in the hypotaxis level as well (NEVES, 2001).

\section{PARATAXIS Independent sentences (-) Demotion \\ Continuum of \\ Demotion \\ EMBEDDED \\ Rulled sentence \\ (+) Demotion}

Figure 2 - Continuum of demotion (declassification)

Source: Lehmann (1988, p. 7), translated by one of the authors of this paper.

A new diagram of continuum is presented by Lima (2002), which is also based on the discussions presented above (dependence, integration and the possibilities of crossing the tactic and logicalsemantic axis). The proposal emerges to pave the way to the analysis of complex sentences in Portuguese, specifically for the adverbial hypotactic relations based on the language in use, which can be employed to analyze sentences in Libras as well. Figure 3 depicts this continuum.

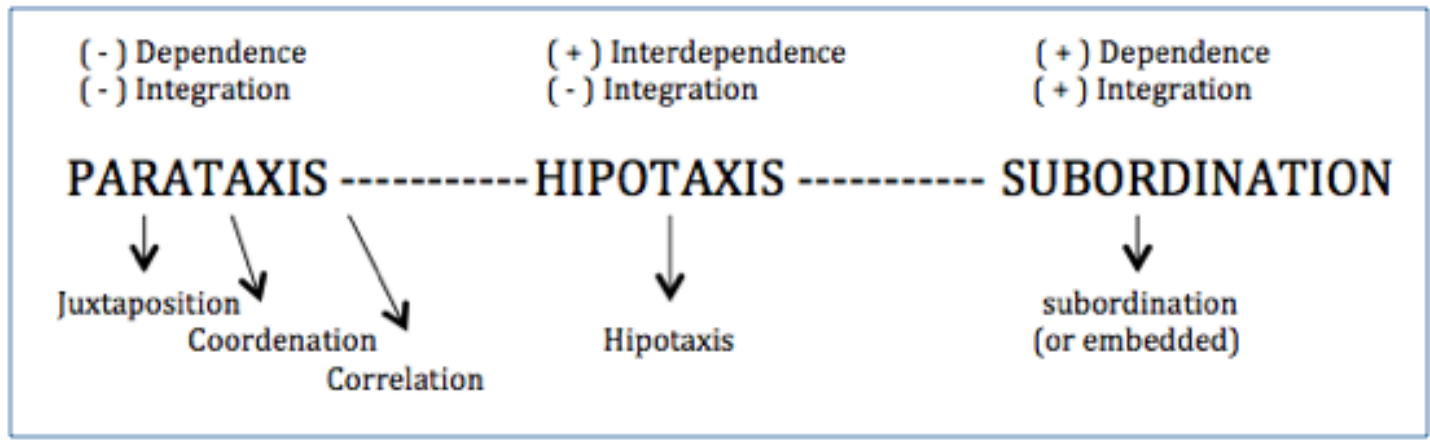

Figure 3 - Continuum of articulation of sentences (LIMA, 2002)

Source: Lima (2002, p. 88), translated by one of the authors of this paper. 
SENTENCE ARTICULATION IN BRAZILIAN

\section{SIGN LANGUAGE}

It is not an easy task to identify the relations that are established in complex sentences in a determine language. Such challenge becomes more difficult in sign languages, since they are relatively 'younger' than the oral languages. According to Tang and Lau (2012), linguists that describe sign languages are still defied by identifying objective criteria and a standard methodology to establish the limits of the sentence. According to the authors, there are few reports on the use of conjunctions in sign languages. The juxtaposition of sentences seems to be a recurrent strategy, instead of the presence of an explicit conjunction. There are also specific strategies of the gestural visual modality, such as the alternate use of manual articulators (each event is articulated with one of the hands), productive use of the signing space, displacement of the body and nodding. Despite that, there is still little discussion on the role of nonmanual marks in articulating sentences in sign languages.

As mentioned above, nodding seems to play the role of a connector in articulating sentences in sign languages. Such marking happens with a strong extended nodding, accompanying the second sentence, so that it affirms a proposition between the sentences. We present below an example of articulations of sentences in Libras, based on this nodding. The proposition between the sentences seems to establish a relation of condition (first sentence) to fulfill an event (second sentence). The example in Figure 3 was taken from the Prolibras Exam, 2007 edition.

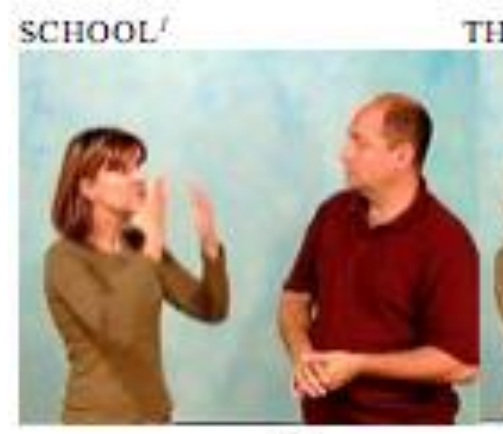

(i)

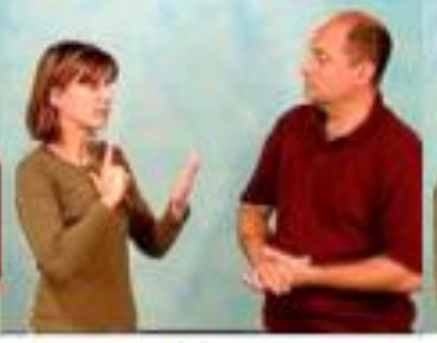

(ii)

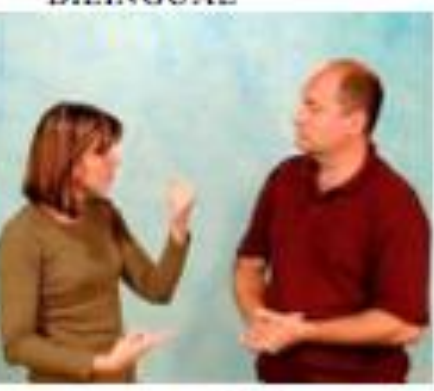

(iii)

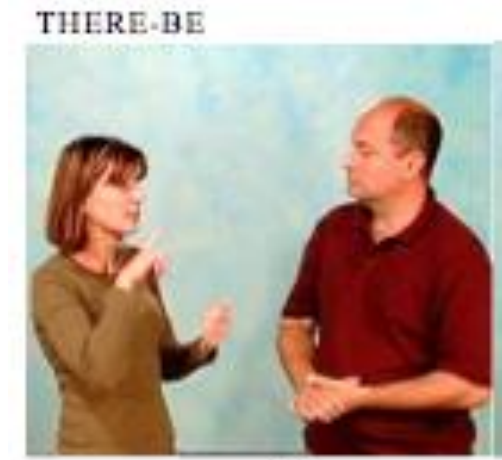

(iv)
TEACHER

DEAF

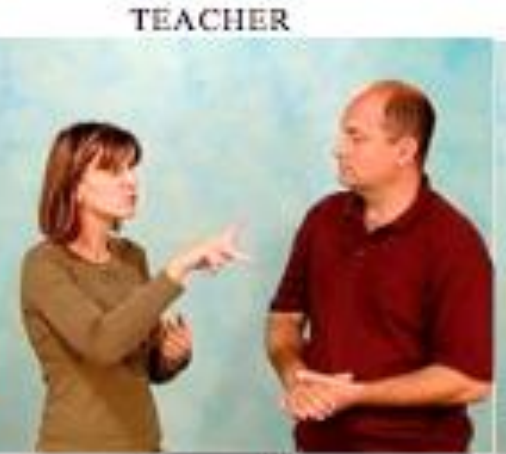

(v)

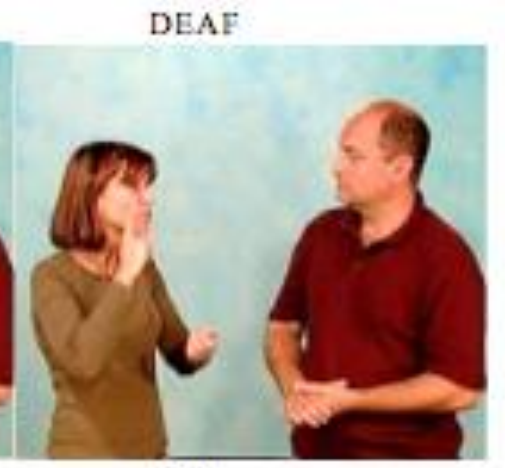

(vi) 


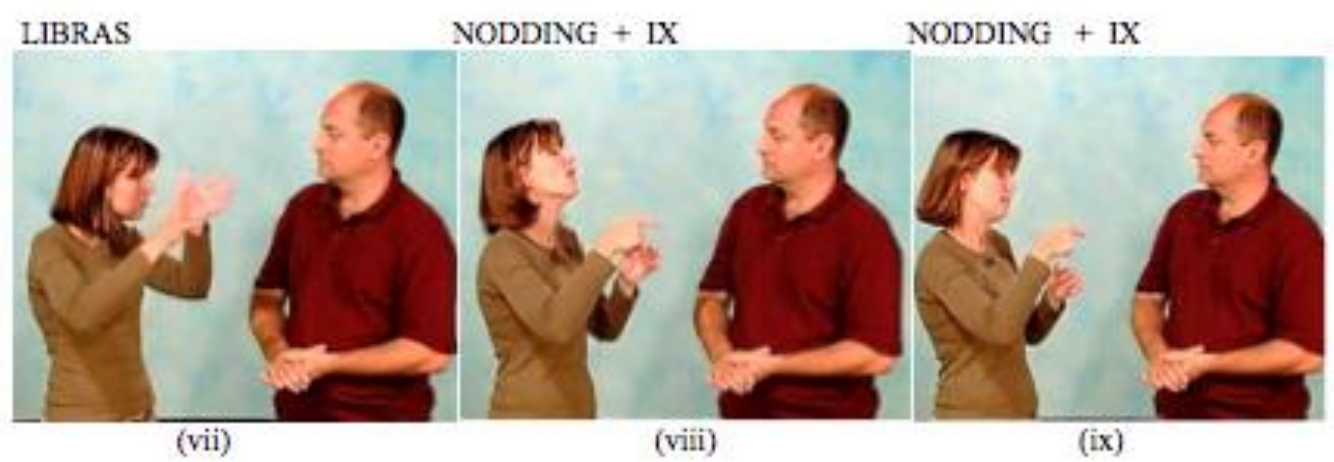

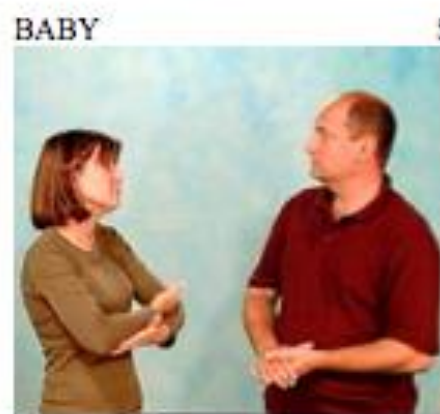

(x)
START

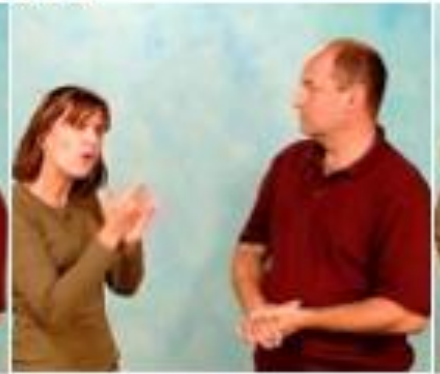

(xi)
EARLY

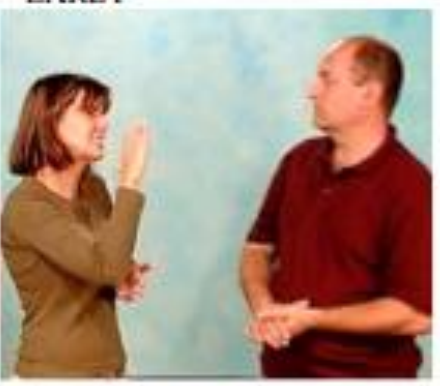

(xii)

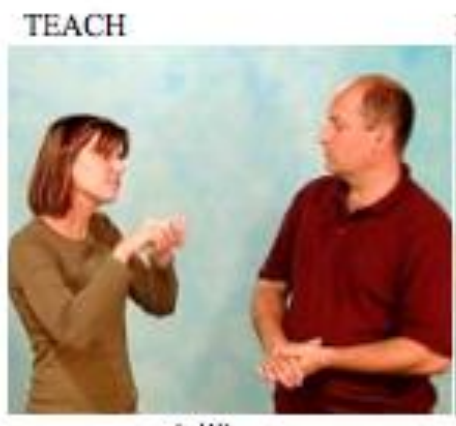

(xiii) LIBRAS

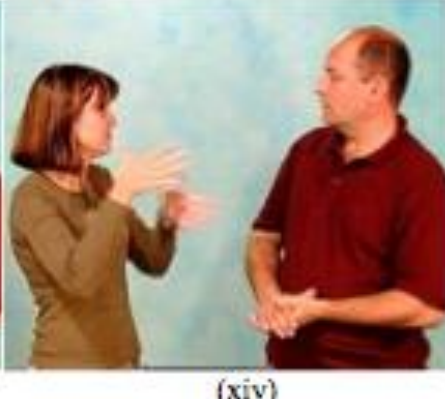

Figure 4. Example of nodding as a connector between sentences. Source: Prolibras, 2007. ${ }^{1}$

Free translation: If there is a bilingual school and there is a signing deaf teacher, the deaf child can be taught in Libras very early.

The construction above is formed by juxtaposed sentences, followed by long nodding, which works as a conjunction in Libras to confirm a condition, so that the following construction may happen.

There are few studies on the articulation of sentences in Libras. Lucinda Ferreira Brito (1995) proposes some discussions on the issue, parting from studies on American Sign Language (ASL). Among these discussions on the topic, there is the inexistence of explicit marks that can differentiate subordinating from the coordinating sentences. She also points out the impossibility of existence of a connector between the main sentence and the subordinating one (embedded).

At this point, we present 9 (nine) complex sentences found in our corpus, ${ }^{2}$ according to the employed criteria. We analyze videos taken from conversations via social networks, produced in bidirectional and asynchronic interaction by three signing deaf of Brazilian sign language. The videos were analyzed on Elan, a multimodal program which enables simultaneous description of audio and/or video. 
Sentences (1) and (2) represent constructions in parataxis relations (one of them is an additional sentence, and the other an oppositional one); sentences (3) until (8) illustrate adverbial hypotaxis relations (one of them is a temporal sentence, three of them are of purpose and two of them of concession) and sentence (9) depicts a relation of subordination.

\section{Parataxis (simple juxtaposition)}

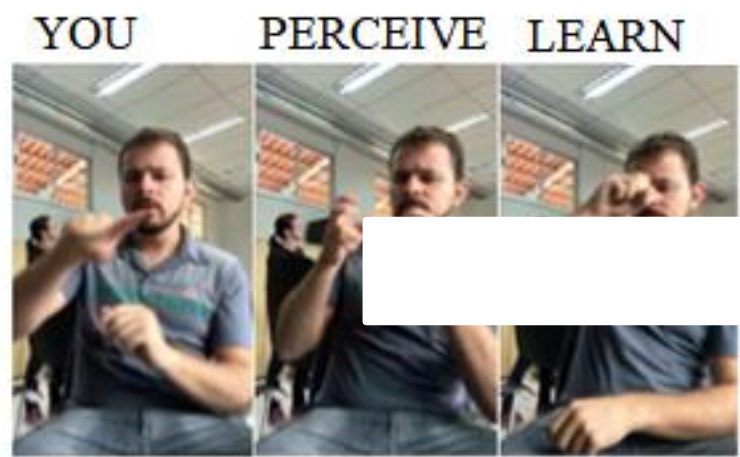

(i) (ii)

Construction 1. Example of Parataxis (simple juxtaposition). Source: Corpus of analysis produced by one the authors.

(1) Free translation: You are going to perceive and learn.

Construction (1) consists of two sentences which are connected by a notion of addition. The juxtaposition is simple, because it does not involve any polarized use of the signing space.

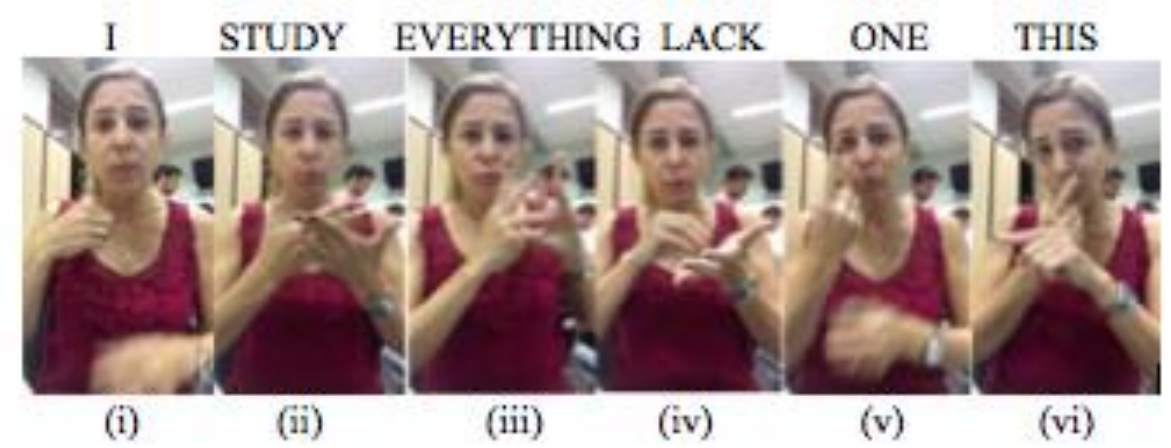

Construction 2. Example of Parataxis (simple juxtaposition).

Source: Corpus of analysis produced by one the authors.

(2) Free translation: I have studied everything, (but) one (topic) is missing, this one.

This construction above consists of two sentences which are connected by a notion of opposition. The juxtaposition is also simple. However, there is no lexical sign that indicates such opposition. Nonetheless, it is just originated from the context of the sentence. 


\section{Adverbial Hypotaxis (tense)}

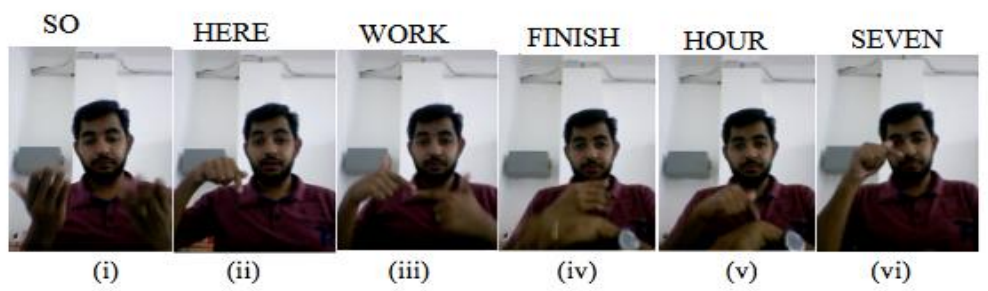

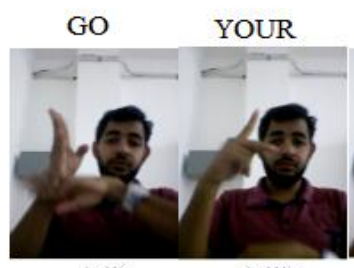

(vii)

(viii)

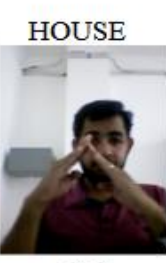

(ix)

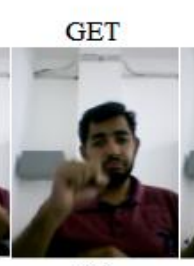

(x)

YOUR

Construction 3. Example of Adverbial Hypotaxis (time).

Source: Corpus of analysis produced by one the authors.

(3) Free Translation: So, my work finishes at 7 o'clock here. I am going to your house to get your (car).

In construction (3), there is a relation of hypotaxis. The first part of the construction, images (i) to (vi), conveys the adverbial sentence which works as a temporal mark for the matrix sentence.

\section{Adverbial Hypotaxis (purpose)}

There is no lexical sign which signals this relation, but only the proposition that is originated from context.
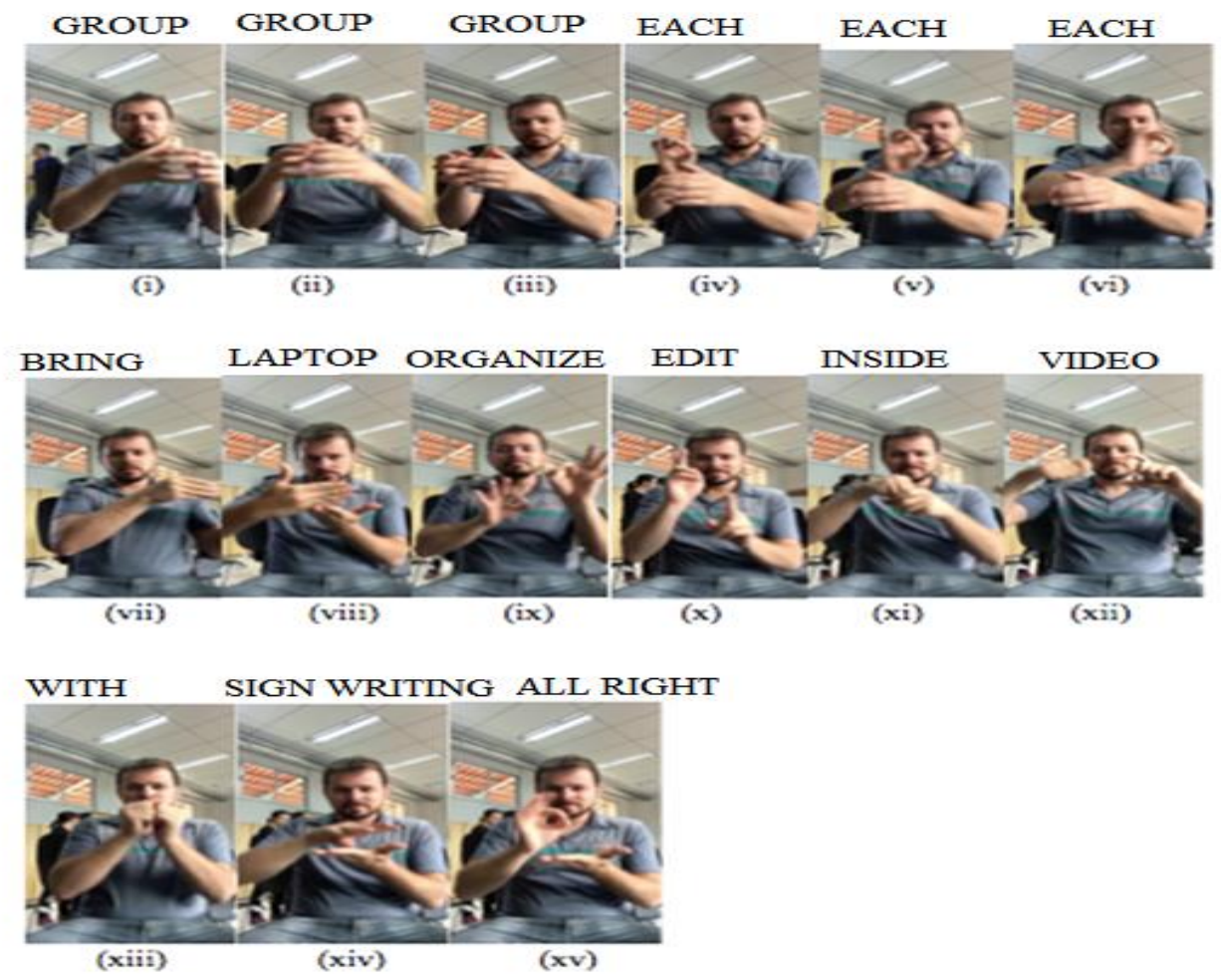

Construction 4. Example of Adverbial Hypotaxis (purpose). 
Source: Corpus of analysis produced by one the authors.

(4) Free translation: Each group is going to bring their laptops (to) organize and edit the video in sign writing, all right?

In construction (4), there is a relation of the context. On Elan, a multimodal transcription adverbial hypotaxis of purpose. The second part of the construction, images (xi) to (xiv), depicts the dependent sentence. There is no lexical sign that indicates such relation, but only the proposition from program, it is possible to perceive that the chin is slightly high, and that there is the narrowing in the eyes. This non-expression mark indicates the sentence of purpose.

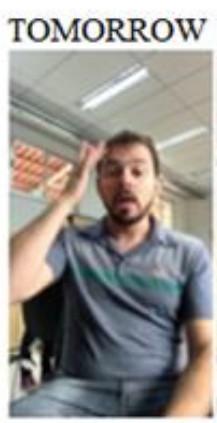

(i)

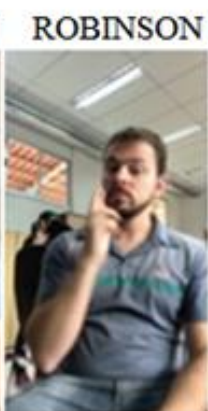

(ii)
HE

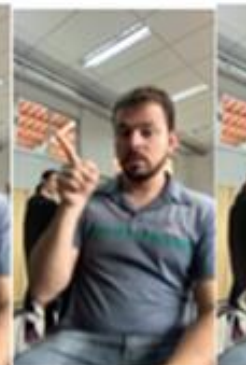

(iii)
COMES TEACH

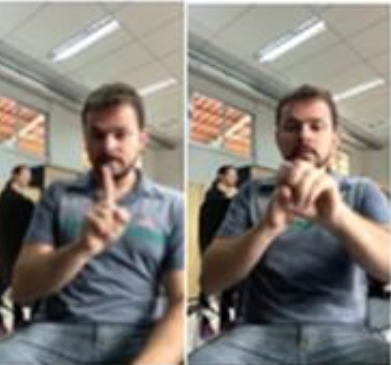

(iv)

(v)

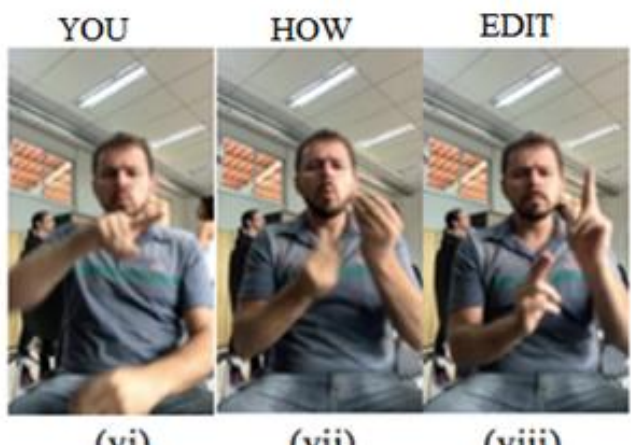

Construction 5. Example of Adverbial Hypotaxis (purpose).

Source: Corpus of analysis produced by one the authors.

(5) Free translation: Tomorrow Robinson comes (to) teach you how to edit.

In Construction (5), there is also an adverbial hypotaxis of purpose. The second part of the construction, images (v) to (viii), pertains to the dependent sentence. There is no lexical sign which indicates such relation, but only the proposition which is perceived from the context. 


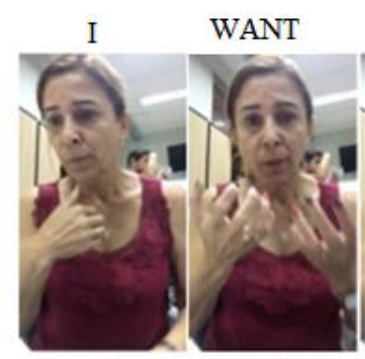

(i) (ii)

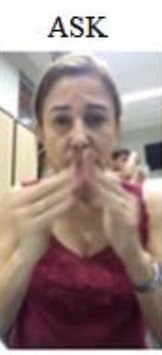

(iii)

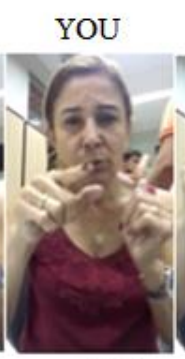

(iv) LITTLE

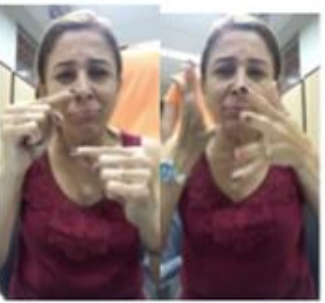

(v) (vi)

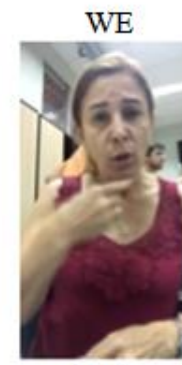

(vii)

ONLY PONDER

OK

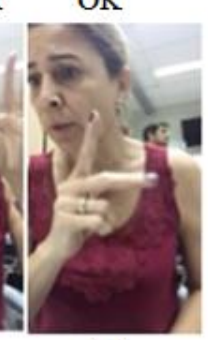

(x)

Construction 6. Example of Adverbial Hypotaxis (purpose).

Source: Corpus of analysis produced by one the authors.

(6) Free translation: I would like to ask you (to) explain it to us a little bit, just to ponder about it, ok?

In construction (6), the adverbial hypotaxis sentence of purpose begins in image (vii) and goes until image (ix), the dependent sentence. Once again, there is no lexical sign that indicates such relation, but only the proposition which stems from the context.

\section{Adverbial Hypotaxis (Condition)}

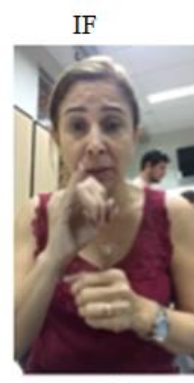

(i)

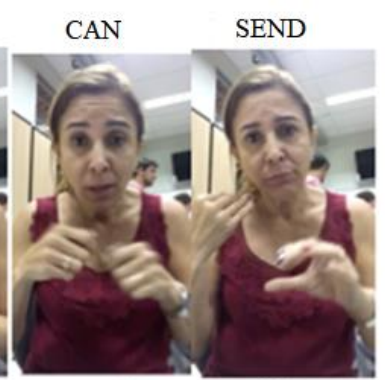

(ii) (iii)

Construction 7. Example of Adverbial Hypotaxis (condition). Source: Corpus of analysis produced by one the authors.

(7) Free translation: If (you) could send it to me via e-mail.

In construction (7), there is an adverbial hypotaxis relation of condition. In the first part of the construction, images (i) and (ii) represent the dependent sentence. There is a lexical sign which signal this relation (if) in image (i). There is a typical facial expression, perceived in images (i) and (ii), which enhance such relation. 


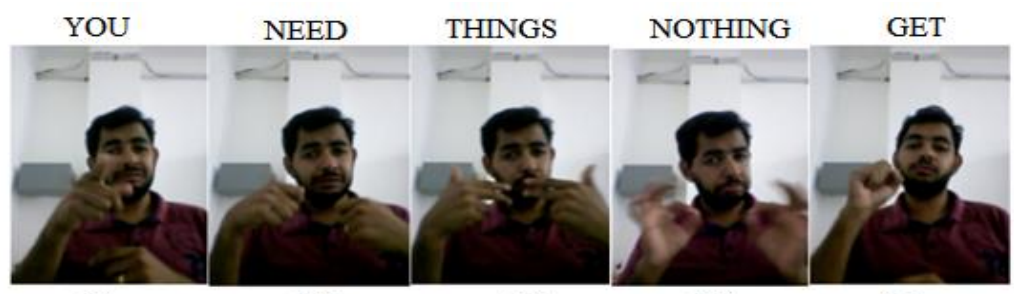

(i)

(ii)

(iii)

(iv)

(v)

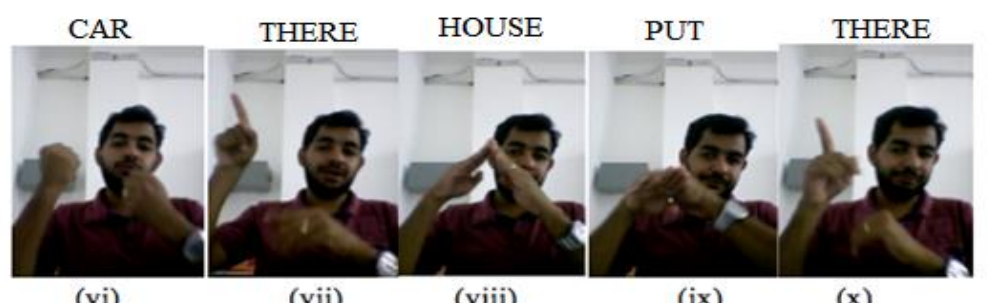

(vi)

(vii)

(viii)

(ix)

(x)

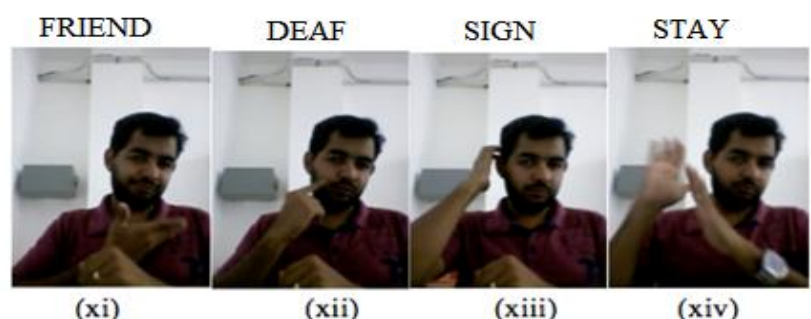

(xi)

(xii)

(xiii)

(xiv)

Construction 8. Example of Adverbial Hypotaxis (condition). Source: Corpus of analysis produced by one the authors.

(8) Free translation: (If) you won't need the car, I can get it and put it in the garage at my deaf friend's house. (The car) can stay there.

In construction (8), there is also an adverbial hypotaxis relation of condition. In the first part of the construction, imagens (i) to (iv) represent the dependent sentence. There is no lexical sign that indicates such relation, but only the typical facial expression which covers the whole dependent sentence, as we have already seen at construction (7).

\section{Subordination (embedded)}

Construction (9) is an example of an embedded articulation. The matrix sentence starts at image (i) and goes until image (iii) and the subordinate sentence, which plays the role of the object of the first one, starts at image (iv) and goes until image (vii). This means that the second sentence takes part of the argument structure of the first sentence. The articulation happens by juxtaposition.

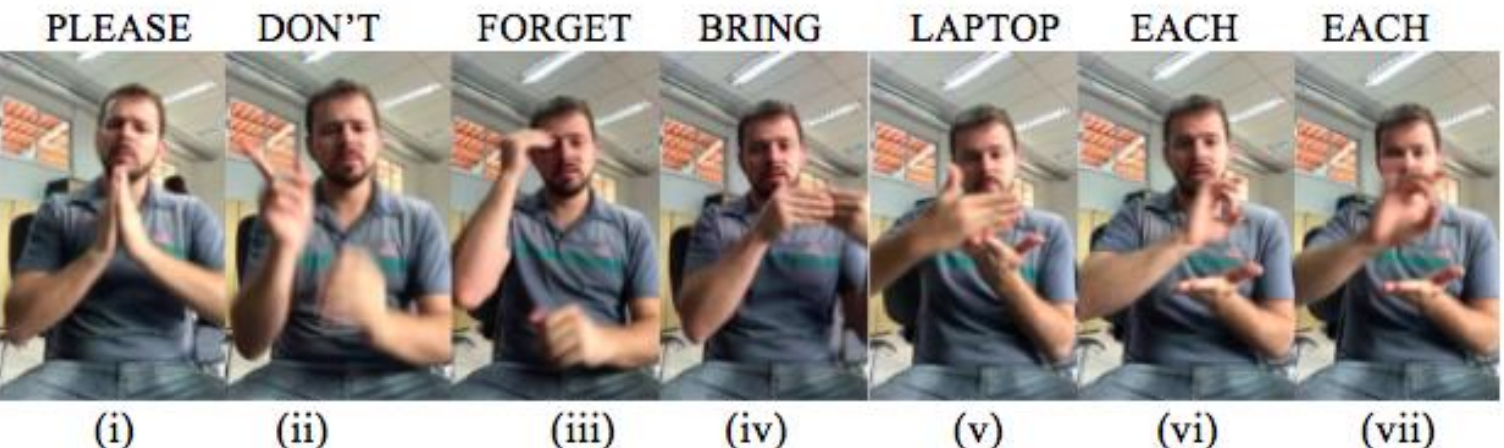

Construction 9. Example of embedded Articulation. 
(9) Free translation: Please, don't forget to bring your laptops.

Considering the complex constructions of our corpus of analysis, we can observe that the strategies of juxtaposition are common in Libras, whose proposition enables the relations of parataxis, hypotaxis and embedded. These (preliminary) findings enhance the view regarding the inner working from the proposition established between the sentences in the utterance.

Only one out of nine constructions presented in this analysis display a lexical item whose function seem to establish an adverbial hypotaxis relation of condition. This lexical item is generally glossed as "IF". Nevertheless, we could also find two examples wherein this kind of relationship is established without this item. In both situations, there is a pattern of facial expression which characterize such relation.

Even though this is an on-going research, we could analyze some preliminary data which indicate some patterns in complex sentence articulations in Libras. All in all, in our corpus, we can state, until the moment of our research, that the juxtaposition seems an important strategy in articulating sentences in Libras, in the relations of the parataxis, hypotaxis and embedded level. Specifically, we observe the signer's specific facial expressions, such as frowning, in the sentence which expresses condition, as well as the elevation of the chin and narrowing of the eyes, in the sentence which conveys purpose. Furthermore, we could find the item "IF" used as a lexical mark to indicate complex relations of condition in libras in one of sentences. We suggest that the item "IF" evidences the relation of condition, and yet it does determine it, once we can observe examples of conditionals without this item in Brazilian sign language.

Therefore, different discursive strategies were found: the use of juxtaposition to articulate sentences, specific facial expressions and the use of lexical items to characterize different complex relations, which emphasize the richness and creativity of Brazilian sign language. Thus, complex sentences in Brazilian sign language embodies different discursive strategies to convey parataxis, hypotaxis and embedded.

Brazilian sign language possesses other linkers and connectors which establish these complex relations, such as because, also, but, so, therefore, and many others. Therefore, we can state that Libras display a large range of complex sentences articulated with different discourse strategies as any natural language do. Since this is an on-going research, we may identify other strategies, which are specific to the visual-gestural modality. Additionally, we may find out the existence of other grammatical elements which might function to establish sentence articulations in Libras. Thus, more data and research are necessary for a rather robust description, so that one can state more consistent generalizations.

\section{FINAL REMARKS}

The articulation of sentences is a linguistic phenomenon which is perceived in a continuum in a gradient way, involving 
parataxis, hypotaxis or embedded. This articulation is processed from the integration of the syntactic, semantic and pragmatical levels of the language in use. In that sense, it is a discursive strategy found in any natural language, independent of the modality, whether it be aural-auditive or visual-spatial. We highlight that the current study is based on a functionalist perspective of language, as well as it just presents some initial considerations which will be further developed in future researches. It is an on-going research and we present some preliminary findings here.

The objective of this article was to describe the process of articulating sentences in Brazilian sign language. We analyzed videos from conversations on the social networks, produced by three deaf in bidirectional and asynchronic interactions. Based on this corpus of research, we identify some strategies of articulating sentences in Libras, considering the relations of parataxis, hypotaxis and embedded.

We suggest that the juxtaposition seems to be an important strategy in the articulation of sentences in Libras, regarding parataxis, hypotaxis and embedded. In the relations of hypotaxis level, we found the presence specific facial expressions, such as frowning, in sentences of condition, and elevation of the chin and narrowing of the eyes, in sentences conveying purpose. Moreover, we found the use of the item 'IF', indicating conditional sentences. Thus, it is very important to conduct further researches to find out patterns using facial expressions to mark complex sentences in Brazilian sign language.

Once again, we present here initial results found out in our analysis. We will pursue the description of strategies of articulating sentences in Libras which, as any natural language, displays diverse discursive strategies, based on the principles of linguistic creativity and economy.

\section{REFERENCES}

BRAGA, Maria Luiza. Processos de combinação de orações: enfoques funcionalistas e gramaticalização. Scripta. Belo Horizonte, v. 5, n.9, p. 23-34, $2^{\circ}$ semestre, 2001.

CARVALHO, Cristina dos Santos. Processos sintáticos de articulação de orações: algumas abordagens funcionalistas. Veredas. Juiz de Fora, v. 8, n.1, p. 9-27, jan/dez, 2004.

CUNHA, Angélica Furtado da. Funcionalismo. In: MARTELOTTA, Mário Eduardo (Org.). Manual de Linguística. São Paulo: Editora Contexto, $2^{\mathrm{a}}$ edição, 2013, p. 157-176.

HALLIDAY, M, A. K. An introduction to functional grammar. Great Britain, Edward Arnold, 1985.

JOHNSTON, Trevor; SCHEMBRI, Adam. On defining lexeme in a signed language. Sign Language \& Linguistics, [s.1.], v. 7, n. 1, p.115-185, 1999.

LELAND, McCleary; VIOTTI, Evani. Transcrição de dados de uma língua sinalizada: um estudo piloto da transcrição de narrativas na língua de sinais brasileira (LSB). In: LIMA-SALLES, Heloisa Maria Moreira. Goiânia: Cânone Editoração, 2007, p. 73-96. LELAND, McCleary; VIOTTI, Evani; LEITE, Tarcísio de Arantes. Descrição das línguas sinalizadas: a questão da transcrição dos dados. Alfa. São Paulo, v. 54, n.1, p. 265-289, 2010.

NEVES, Maria Helena de Moura. Estudar os usos linguísticos. Ou: a visão funcionalista da 
linguagem. In:

Texto e gramática.

São Paulo: Editora Contexto, 2006, p. 15-34.

NEVES, Maria Helena de Moura. O tratamento da articulação de orações. In:

Descrição do português: definindo rumos de pesquisa. São Paulo: Cultura Acadêmica Editora, 2001, p. 55-66.

PEZATTI, Erotilde Goreti. O funcionalismo em linguística. In: MUSSALIM, Fernanda; BENTES, Anna Christina. (Orgs.). Introdução à linguística. Fundamentos epistemológicos. Volume 3. São Paulo: Cortez Editora, $3^{a}$ edição, 2007, p. 165-218.

QUADROS, Ronice M. de.; SCHMITT, Deonísio; LOHN, Juliana T.; LEITE, Tarcísio de A.; e colaboradores. Corpus de Libras. http://corpuslibras.ufsc.br/ LEHMANN, Christian. Toward a typology of clause linkage. In: HAIMAN, J. \& THOMPSON, S. (Eds.). Clause combining in grammar and discourse. Amsterdam/ Philadelphia: John Benjamins, 1988, p. 181225.

LIMA, Ana. Relações hipotáticas adverbiais na interação verbal. 190f. Tese (Doutorado em Lingüística e Língua Portuguesa) Faculdade de Ciências e Letras, Universidade Estadual Paulista Júlio de Mesquita Filho, Araraquara, 2002.

TANG, Gladys; LAU, Prudence. Coordination and subordination. In: PFAU, Roland; STEINBACH, Markus; WOLL, Bencie. (Eds.). Sign Language. An International Handbook. Berlin: Mouton de Gruyter, 2012. p. 340-365.

ZESHAN, Ulrike. 'Classificatory constructions in Indo-Pakistani sign language: Grammaticalization and lexicalization processes. In: EMMOREY, Karen. Perspectives on classifier constructions in sign languages. Mahwah: Lawrence Erlbaum Associates, 2003b. Cap. 6. p. 113-141. 